\title{
First report and molecular characterization of Trypanosoma vivax in cattle from state of Pernambuco, Brazil
}

\author{
Danillo de Souza Pimentel ${ }^{\mathrm{a}}$, Carlos Alberto do Nascimento Ramos ${ }^{\mathrm{a}}$, \\ Rafael Antônio do Nascimento Ramos ${ }^{a, *}$, Flábio Ribeiro de Araújo ${ }^{b}$, Mario Lins Borbac ${ }^{c}$, \\ Maria Aparecida da Gloria Faustino ${ }^{\mathrm{a}}$, Leucio Câmara Alves ${ }^{\mathrm{a}}$ \\ a Universidade Federal Rural de Pernambuco, Departamento de Medicina Veterinária, Av. Dom Manoel de Medeiros s/n, CEP 52171-900, Recife, PE, Brazil \\ b Embrapa Gado de Corte, Área de Sanidade Animal, Br 262, Km 04, Caixa Postal 154, CEP 79002-970, Campo Grande, MS, Brazil \\ c Autonomous Veterinary, Av. Lauro Borba, 608, CEP 55870-000, Timbaúba, PE, Brazil
}

\section{A R T I C L E I N F O}

\section{Article history:}

Received 12 May 2011

Received in revised form 12 October 2011

Accepted 13 October 2011

\section{Keywords:}

Trypanosoma vivax

Parasitological diagnosis

Molecular diagnosis

Epidemiology

\begin{abstract}
A B S T R A C T
This paper describes an outbreak of Trypanosoma vivax for the first time in the state of Pernambuco, Brazil, affecting dairy cattle in the municipality of Itambé in the northern coastal zone of the state. Clinical signs compatible with infection by blood protozoa and epidemic miscarriages were observed. The diagnosis of $T$. vivax was confirmed through biometric microscopy and molecular analysis with PCR and DNA sequencing. The T. vivax isolate detected in the present study proved to be genetically very close to other Brazilian isolates of the protozoan despite being geographically distant.
\end{abstract}

(c) 2011 Elsevier B.V. All rights reserved.

\section{Introduction}

The protozoan Trypanosoma (Duttonella) vivax Ziemann (1905) infects a large variety of wild and domestic ungulates, among which cattle are the most susceptible (D'Ávila et al., 1997). T. vivax is believed to have been introduced in the Americas in the mid 19th century, when Zebu cattle from Senegal were imported to French Guyana and the Antilles. Diffusion throughout the region likely occurred due to the adaptation of the parasite to mechanical transmission carried out by hematophagous dipterans, such as Tabanus spp. and Stomoxys spp.; however, the biological vectors in these regions remain unknown (Shaw and Lainson, 1972; Clarkson, 1976; Gardiner, 1989; Paiva et al., 2000; Osório et al., 2008).

In Brazil, T. vivax was first described in the northern and central western regions (Shaw and Lainson, 1972; Serra-

\footnotetext{
* Corresponding author. Tel.: +55 8133206422 .

E-mail address: rafaelanramos@yahoo.com.br (R.A.N. Ramos).
}

Freire, 1981; Silva et al., 1996; Paiva et al., 1997) and also has recently been described infecting cattle, buffalo and sheep in the northeastern region of Brazil (Batista et al., 2007; Guerra et al., 2008; Galiza et al., 2011; Melo et al., 2011), cattle in the southeastern (Carvalho et al., 2008) regions as well as horses in the southern region of the country (Silva et al., 2011).

Cattle infected by $T$. vivax may be completely asymptomatic or may exhibit severe hematological alterations leading to pale mucous membranes, progressive weight loss and miscarriage (Silva et al., 1999). Although this protozoan lives in balance with its vertebrate host throughout most of Brazil, clinical and hematological alterations have occurred in a sporadic, localized fashion (Barbosa et al., 2001; Linhares et al., 2006; Batista et al., 2007).

Despite the geographic proximity to the state of Paraíba (northeastern Brazil), where T. vivax has recently been identified (Batista et al., 2007; Galiza et al., 2011), this protozoan has not previously been reported for the state of Pernambuco. Thus, this paper reports the occurrence of $T$. vivax in cattle for the first time in the state of 
Pernambuco and offers the molecular characterization of the isolate found.

\section{Materials and methods}

An outbreak of trypanosomiasis by $T$. vivax occurred in the month of March 2010, which is the beginning of the rainy season in the region, on a dairy cattle farm located in the municipality of Itambé $\left(07^{\circ} 26^{\prime} 40^{\prime \prime} \mathrm{S}\right.$ and $\left.35^{\circ} 14^{\prime} 17^{\prime \prime} \mathrm{W}\right)$ in the state of Pernambuco (northeastern Brazil).

From a total of 80 cattle, 22 (27.5\%) showed hyperthermia, anorexia, pale mucous membranes, aqueous diarrhea of dark coloration, reduction in milk production, the occurrence of premature fetuses and a higher than average number of miscarriages for the farm. Blood samples of jugular vein from these 22 animals with hyperthermia were collected with EDTA. For parasitological exam blood smears were prepared and stained with Giemsa stain.

For the molecular diagnosis, DNA was extracted from $350 \mu \mathrm{L}$ of blood using the method described by Araújo et al. (2009). The diagnosis was carried out in two steps. The first step was polymerase chain reaction (PCR) using the procedure described by Geysen et al. (2003), using the generic primers 18STnF2 (5'-CAACGATGACACCCATGAATTGGGGA$\left.3^{\prime}\right)$ and 18STnR3 (5'-TGCGCGACCAATAATTGCAATAC-3'), which delimit a fragment of $659 \mathrm{bp}$ of the 18S rRNA gene in Brazilian isolates of T. vivax (Madruga et al., 2003). The second step was carried out through the sequencing of the amplicons obtained from the PCR.

A pool of the amplicons was used for binding to the pGem-T Easy plasmid (Promega). Five clones of the recombinant plasmid were sequenced using the method described by Sanger et al. (1977) in an ABI 3130 automatic sequencer (Applied Biosystems). The Sequencher 4.1.4 program (Gene Codes) was used for the editing and generation of the consensus sequence. A search by homology was then carried out using the BLASTn algorithm (http://www.ncbi.nlm.nih.gov/BLAST) (Altschul et al., 1990). The phylogenetic analysis was carried out using the MEGA 4.0 program (Tamura et al., 2007) and the phylogenetic tree was constructed using the neighbor-joining method (Saitou and Nei, 1987), involving a bootstrap procedure with 1000 replicates (Felsenstein, 1985).

\section{Results}

During the clinical exam, besides hyperthermia, 13.63\% (3/22) of the animals were prostrate and had reduced milk production, premature offspring and miscarriages in the final third of the gestation. The protozoan was observed microscopically in $9.09 \%(2 / 22)$. No other blood parasites, such as Babesia sp. and Anaplasma marginale, were observed in the microscopic exam.

The morphometric analysis of the protozoan revealed the following dimensions: total size $=20 \mu \mathrm{m}$; distance from kinetoplast to posterior region $=1.0 \mu \mathrm{m}$; distance from kinetoplast to nucleus $=5.7 \mu \mathrm{m}$; distance from posterior region to nucleus $=6.0 \mu \mathrm{m}$; distance from nucleus to anterior region $=8.0 \mu \mathrm{m}$; and free flagellum $=6.0 \mu \mathrm{m}$. These measurements are in agreement with those obtained

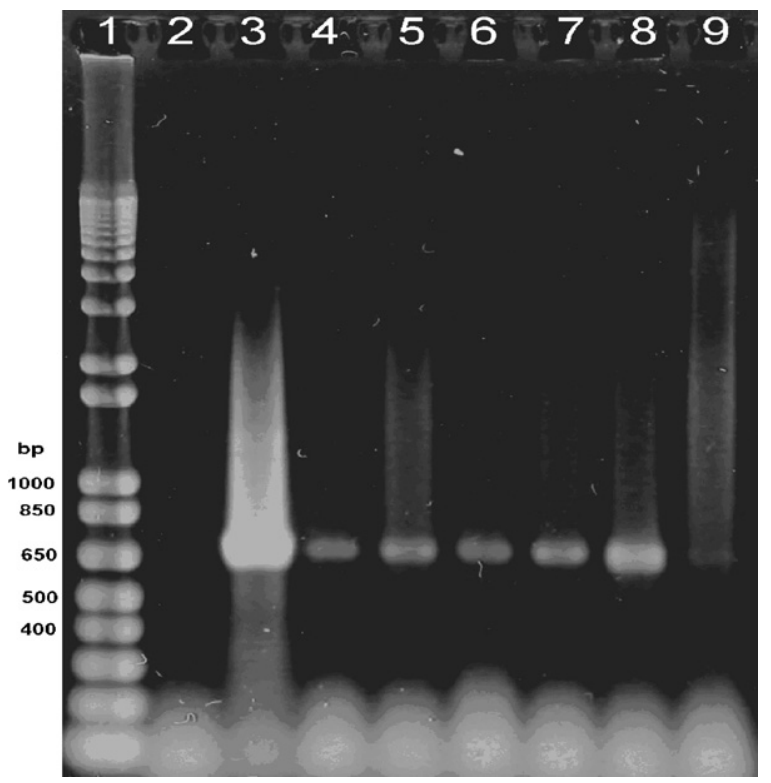

Fig. 1. Electrophoresis in $1 \%$ agarose gel of PCR amplification of $18 \mathrm{~S}$ rRNA gene from Trypanosoma vivax; (1) base pair marker (1 kb plus Invitrogen); (2) negative control; (3) positive control; (4-9) amplifications from DNA extracted from blood of bovines suspected of trypanosomiasis.

for other New World isolates of T. vivax (Johnson, 1941; Shaw and Lainson, 1972; Oliveira et al., 2009).

In the molecular diagnosis (PCR), 100\% (22/22) of the animals from which blood samples were collected were positive for Trypanosoma sp. following the viewing of amplicons of approximately $650 \mathrm{bp}$ (Fig. 1).

In the homology search of the sequenced amplicons with the aid of the BLASTn algorithm, 99\% identity was found between the sequences of the 18S rRNA gene in the present study and sequences from Brazilian isolates of T. vivax (Aquidauana AY362546, Belém AY363164 and Poconé AY363165) as well as an African isolate (Nigeria U22316).

The partial sequence of the 18S rRNA gene of the Itambé/PE isolate of $T$. vivax was deposited in the Genbank under accession number HM209400.

The phylogenetic analysis revealed that the Brazilian isolates are grouped together with an isolate from west Africa (Nigeria) and separated from an isolate found in antelopes (Tragelaphus angasi) in Mozambique (east Africa) (Fig. 2).

\section{Discussion}

According to Geysen et al. (2003), the primers used in the present study delimit fragments between 700 and $800 \mathrm{bp}$, based on the species of Trypanosoma involved. Using these same primers, Madruga et al. (2003) found that the amplified fragment was $659 \mathrm{bp}$ for Brazilian isolates of Trypanosoma vivax. Therefore, the amplicons obtained in the present study were compatible in size to those described for Brazilian isolates of T. vivax (Madruga et al., 2003). 


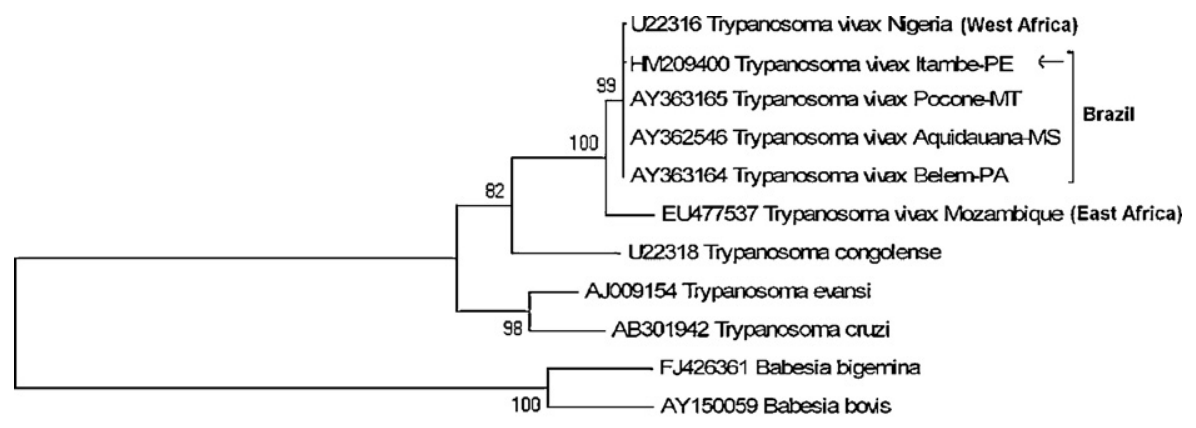

0.1

Fig. 2. Phylogenetic tree constructed using neighbor-joining method with sequences of 18S rRNA gene of Trypanosoma vivax isolates, other species of Trypanosoma sp., Babesia bigemina and Babesia bovis; number at each knot corresponds to bootstrap percentage derived from 1000 replicates; scale represents number of replacements per site of sequence.

Although genetic polymorphism is reported between isolates of T. vivax from the Pantanal wetlands of Brazil by RAPD, REP and ERIC-PCR (Osório, 2002), the genetic diversity of New World isolates of T. vivax is lesser than that of African isolates (Cortez et al., 2006), as geographically distant Brazilian isolates [Aquidauana and Poconé (central western region), Belém (northern region) and Itambé (northeastern region)] are genetically very close to one another. This low degree of diversity is likely due to the absence of genetic recombination in the parasite, which normally occurs in its biological vector (Gibson, 1995), thereby enabling the maintenance of the parasite/host balance in the New World bovine population, unlike what occurs in Africa (Osório et al., 2008).

The results of phylogenetic analysis corroborate with observations put forth by Cortez et al. (2006) and Rodrigues et al. (2008) and the hypothesis of a west African origin for South American isolates of T. vivax.

The pathway of T. vivax introduction in the State of Pernambuco remains unknown, as no animals were recently introduced on the farm of occurrence. However, it is likely that this introduction occurred through the transit of chronically infected animals (cattle, buffalo or small ruminants) from regions of occurrence to protozoan-free regions (Batista et al., 2007). Moreover, as the property studied has a high density of hematophagous flies, the dissemination of the parasite may have occurred through mechanical transmission by these insects, which are likely the transmitters of this protozoan in the Americas (Otte et al., 1994; Jones and Dávila, 2001).

\section{Conclusion}

The outbreak of trypanosomíasis by T. vivax described for the first time in the state of Pernambuco and previous descriptions of outbreaks in Brazil demonstrate that this protozoan is spreading throughout the country, which can cause serious problems in susceptible herds. Therefore, greater attention and control are needed regarding the transit of animals from regions in which the parasite is present to regions that remain free of this parasite in order to avoid economic losses stemming from the establishment of the parasite, especially in cattle herds.

\section{References}

Altschul, S.F., Gish, W., Miller, W., Myers, E.W., Lipman, D.J., 1990. Basic local alignment search tool. J. Mol. Biol. 215, 403-410.

Araújo, F.R., Ramos, C.A.N., Luiz, H.L., Pérez, I.A.H.F.S., Oliveira, R.H.M., Souza, I.I.F., Russi, L.S., 2009. Avaliação de um protocolo de extração de DNA genômico a partir de sangue total. Embrapa Gado de Corte, 5 pp. (Embrapa Gado de corte. Comunicado Técnico, 120). Disponível em http://www.cnpgc.embrapa.br/publicacoes/cot/COT120.

Barbosa Jr., N.S., Madruga, C.R., Osório, A.L.A.R., 2001. Descrição de surto de tripanossomose bovina por Trypanosoma vivax, com morte perinatal no Pantanal de Aquidauana, MS. In: Congresso Brasileiro de Buiatria, Campo Grande, 2001. Anais, Campo Grande, p. 135.

Batista, J.S., Riet-Correa, F., Teixeira, M.M., Madruga, C.R., Simões, S.D., Maia, T.F., 2007. Trypanosomiasis by Trypanosoma vivax in cattle in the Brazilian semiarid: description of an outbreak and lesions in the nervous system. Vet. Parasitol. 143, 174-181.

Carvalho, A.U., Abrão, D.C., Facury Filho, E.J., Paes, P.R.O., Ribeiro, M.F.B., 2008. Ocorrência de Trypanosoma vivax no estado de Minas Gerais. Arq. Bras. Med. Vet. Zootechn. 60, 769-771.

Clarkson, M.J., 1976. Trypanosomiasis of domesticated animals of South America. Trans. R. Soc. Trop. Med. Hyg. 70, 125-126.

Cortez, A.P., Ventura, R.M., Rodrigues, A.C., Batista, J.S., Paiva, F., Añez, N., Machado, R.Z., Gibson, W.C., Teixeira, M.M., 2006. The taxonomic and phylogenetic relationships of Trypanosoma vivax from South America and Africa. Parasitology 133, 159-169.

D’Ávila, A.M.R., Ramirez, L., Silva, R.A.M.S., 1997. Morphological and biometrical differences among Trypanosoma vivax isolates from Brazil and Bolívia. Mem. Inst. Osw. Cruz. 92, 357-358.

Felsenstein, J., 1985. Confidence limits on phylogenies: an approach using the bootstrap. Evolution 39, 783-791.

Galiza, G.J.N., Garcia, H.A., Assis, A.C.O., Oliveira, D.M., Pimentel, L.A., Dantas, A.F.M., Simões, S.V.D., Teixeira, M.M.G., Riet-Correa, F., 2011. High mortality and lesions of the central nervous system in Trypanosomosis by Trypanosoma vivax in Brazilian hair sheep. Vet. Parasitol. doi:10.1016/j.vetpar.2011.05.016.

Gardiner, P.R., 1989. Recent studies of the biology of Trypanosoma vivax. Adv. Parasitol. 28, 229-317.

Geysen, D., Delespaux, V., Geerts, S., 2003. PCR-RFLP using SSUrDNA amplification as an easy method for species-specific diagnosis of Trypanosoma species in cattle. Vet. Parasitol. 110, 171-180.

Gibson, W., 1995. The significance of genetic exchanges in trypanosomes. Parasitol. Today $11,465-468$.

Guerra, R.M.S., Feitosa Jr., A.B., Santos, H.P., Silva, A.L.A., Santos, C.G., 2008. Biometry of Trypanosoma vivax found in a calf in the state of Maranhão, Brazil. Cienc. Rural 38, 833-835.

Johnson, C.M., 1941. Bovine trypanosomiasis in Panama. Am. J. Trop. Med. Hyg. 21, 289-297.

Jones, T.W., Dávila, A.M.R., 2001. Trypanosoma vivax out of Africa. Trends Parasitol. 17, 99-101.

Linhares, G.F.C., Dias Filho, F.C., Fernandes, P.R., Duarte, S.C., 2006. Tripanossomíase em bovinos no município de Formoso do Araguaia, Tocantins (relato de caso). Ci. Anim. Bras. 7, 455-460.

Madruga, C.R., Araújo, F.R., Soares, C.O., Melo, E.S.P., Almeida, D.A., Almeida Junior, N.F., Xavier, M.A.S., Osório, A.L.A., Góes-Cavalcante, G., Ramos, C.A.N., 2003. Diagnóstico molecular e análise filogenética 
de isolados brasileiros de Trypanosoma vivax baseado na reação da polimerase em cadeia - PCR. Embrapa Gado de Corte, 5 pp. (Embrapa Gado de Corte. Comunicado Técnico, 84). Disponível em http://www.cnpgc.embrapa.br/publicacoes/cot/COT84.

Melo, S.A., Barros, A.C., Costa, F.B., de Carvalho Neta, A.V., Guerra, R.M.C., Abreu-Silva, A.L., 2011. Bovine trypanosomiasis an emerging disease in Maranhão State-Brazil. Vect. Born. Zoon. Dis. 7, 853-856.

Oliveira, J.B., Hernández-Gamboa, J., Jiménez-Alfaro, C., Zeledón, R., Blandón, M., Urbina, A., 2009. First report of Trypanosoma vivax infection in dairy cattle from Costa Rica. Vet. Parasitol. 136, 136-139.

Osório, A.L.A.R., 2002. Polimorfismo genético de Trypanosoma (Duttonella) vivax no Pantanal brasileiro e caracterização antigênica e ultraestrutural de suas frações subcelulares. PhD Thesis. Fiocruz, Rio de Janeiro, 105 pp.

Osório, A.L.A.R., Madruga, C.R., Desquesnes, M., Soares, C.O., Ribeiro, L.R.R., COSTA, C.G., 2008. Trypanosoma (Dutonella) vivax: its biology, epidemiology, pathogenesis, and introduction in the New World - a review. Mem. Inst. Osw. Cruz. 103, 1-13.

Otte, M.J., Abuabara, J.Y., Wells, E.A., 1994. Trypanosoma vivax in Colômbia: epidemiology and production losses. Trop. Anim. Health Prod. 26, 146-156.

Paiva, F., Lemos, R.A.A., Oshiro, E.T., Salvador, S.C., Nakasato, L., 1997. Ocorrência de Trypanosoma vivax em bovinos do estado de Mato Grosso do Sul. Rev. Bras. Parasitol. Vet. 6, 349.

Paiva, F., Lemos, R.A.A., Nakasato, L., Mori, A.E., Brum, K.B., Bernardo, K.C., 2000. Ocorrência de Trypanosoma vivax em bovinos do Estado de Mato Grosso do Sul, Brasil I. Acompanhamento clínico, laboratorial e anatomopatológico de rebanhos infectados. Rev. Bras. Parasitol. Vet. 9, 135-141.
Rodrigues, A.C., Neves, L., Garcia, H.A., Viola, L.B., Marcili, A., Da Silva, F.M., Sigauque, I., Batista, J.S., Paiva, F., Teixeira, M.M., 2008. Phylogenetic analysis of Trypanosoma vivax supports the separation of South American/West African from East African isolates and a new T. vivax-like genotype infecting a nyala antelope from Mozambique. Parasitology $135,1317-1328$.

Saitou, N., Nei, M., 1987. The neighbor-joining method: a new method for reconstructing phylogenetic trees. Mol. Biol. Evol. 4, 406-425.

Sanger, F., Nicklen, S., Coulson, A.R., 1977. DNA sequencing with chainterminating inhibitors. Proc. Natl. Acad. Sci. U. S. A. 74, 5463-5467.

Serra-Freire, N.M., 1981. Oiapoque - outro foco de Trypanosoma vivax no Brasil. Rev. Bras. Med. Vet. 4, 30-31.

Shaw, J.J., Lainson, R., 1972. Trypanosoma vivax in Brazil. Ann. Trop. Med. Parasitol. 66, 25-32.

Silva, R.A.M.S., Silva, J.A., Schneider, R.C., Freitas, J., Mesquita, D., Mesquita, T., Ramirez, L., Dávila, A.M.R., Pereira, M.E.B., 1996. Outbreak of Trypanosomiasis due to Trypanosoma vivax (Ziemann, 1905) in bovines of the Pantanal, Brazil. Mem. Inst. Osw. Cruz. 5, 561-562.

Silva, R.A.M.S., Ramirez, L., Souza, S.S., Ortiz, A.G., Pereira, S.R., Dávila, A.M.R., 1999. Hematology of natural bovine trypanosomosis in the Brazilian Pantanal and Bolivian wetlands. Vet. Parasitol. 85 , 87-93.

Silva, A.S., Garcia Perez, H.A., Costa, M.M., França, R.T., De Gasperi, D., Zanette, R.A., Amado, J.A., Lopes, S.T., Teixeira, M.M., Monteiro, S.G., 2011. Horses naturally infected by Trypanosoma vivax in Southern Brazil. Parasitol. Res. 108, 23-30.

Tamura, K., Dudley, J., Nei, M., Kumar, S., 2007. MEGA4: Molecular Evolutionary Genetics Analysis (MEGA) software version 4.0. Mol. Biol. Evol. 24, 1596-1599. 